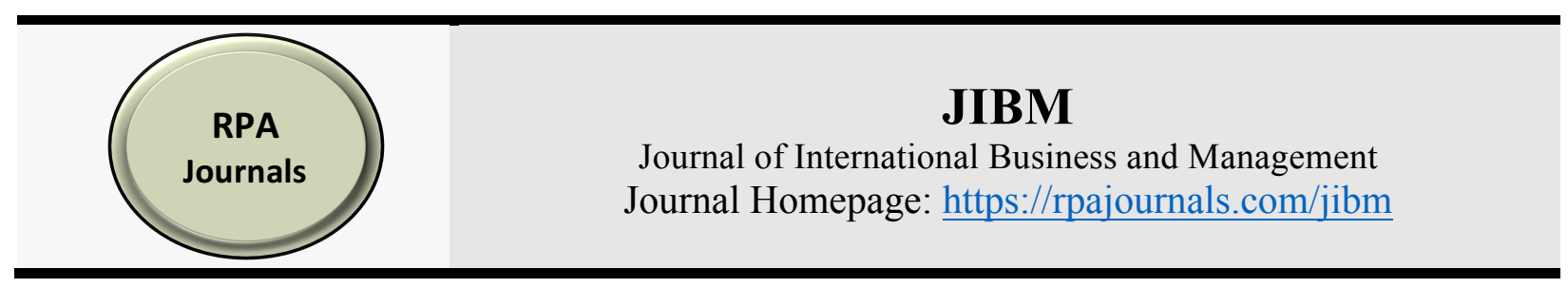

\title{
Impact of Working Capital Policies on Firm's Performance, Evidence from Pakistan
}

\author{
Mushtaq Nadeem ${ }^{1}$ \\ Muhammad Waris ${ }^{2}$ \\ Muhammad Asadullah ${ }^{3}$ \\ Muhammad Kamran ${ }^{4}$ \\ Project Financing MEPCO, Pakistan ${ }^{1}$ \\ Air University, Pakistan ${ }^{2,3}$ \\ Women University, Pakistan ${ }^{4}$
}

\begin{abstract}
The main objective our study is to explore the relationship between working capital policies and firm's performance. Using OLS method to analysis the data after fulfilling the assumption of the regression, this study finds the working capital components (APP, ICP, CCC) and the firms' performance are negatively correlated with the ROA and Tobin-q except ACP which shows significant relationship with Tobin Q. All working capital components show the significant relationship with ROE, which indicates that most firms used shareholder's equity to increase firm's value. The relationship between the APP and the firms' performance has shown mixed results. This study shows that the ACP and the firms' performance are positively related. However, the companies are showing the positive relationship between the ACP and the firms' performance as measured by the ROE and Tobin's Q. This indicates that the shorter ACP in a firm is more preferable to the shareholders. All companies show a positive relationship between the CFP and the firms' performance. The relationship indicates that the conservative financing policy is a policy which carries a higher amount of current liabilities will contribute to negative firms' profitability and value. The negative relationship between the CLTAR and the firms' performance indicates that the higher current liabilities in a firm will be a factor towards lower firms' performance. The aggressive financing policy is only significant in all the independent variables. The ROA found CFP and CIP as significant, while in ROE CFP is significant. AIP, CIP and CFP are significant in Tobin Q.
\end{abstract}

Keywords: CATAR, CLTAR, ROI, ROE, Cash Conversion Cycle

*Corresponding author: Muhammad Waris; Email: warisraobzu051@gmail.com

DOI: https://doi.org/10.37227/jibm-2020-01-26

\section{Introduction}

Working capital management is to make sure that a firm is capable to carry on its operations and that it has adequate ability to satisfy both maturing short-term debt and upcoming operational expenses. The components inside working capital management consist of current assets and current liabilities. The firm liquidity is the difference between current assets and current liabilities. The goal of working capital management is to manage the currents assets and current liabilities of the firms to obtain the balance between profitability and risk that contribute definitely to the firm's value. The components in working capital management 
consist of account receivables, Inventory, account payables, cash conversion cycle. It is essential to have a good evaluation of liquidity of a firm because fall in liquidity can lead to risk of failure. Management of working capital is a key, because it is a vital factor in corporate finance, which is related to short term financing and investment decision of a firm. Working capital management makes sure that a firm has sufficient cash flow to repay its current debts and operating expenses. Large companies have faced liquidity problems in the global economic crisis of 2008. The crisis has brought out awareness among business to unlock their precious money that was tied up in working capital. Net working capital position can affect a firm's ability to obtain debt financing due to the requirement for most financial institutions that require a company to have minimum net working capital position.

Mohamad \& Saad (2010) state that management of working capital requirement is very important to ensure the improvement in the market value of a company and profitability. Many companies that appear to have efficient working capital management earn profits over the year (Appuhami, 2008).A study conducted by Weinraub and Visscher (1998) found that different sectors managed their working capital differently due to their different business activities. For example, the current assets of a manufacturing business over half of its total assets, for distribution business, they required even more. High level of current assets adversely affects the firm profitability. However, the low level may incur problems in smooth running of business. For small businesses, short debts are the basic source of investment. These businesses do not have access to the long-term capital market.

The significance of working capital management of a company may be related to pecking order theory and agency theory. The pecking order theory implies that companies use internal sources prior to using leverage by borrowing or the issuing of shares. Thus can be done using the strategy of aggressive working capital, which is declining the current asset, such as reducing stock level at a minimum and decreasing the credit in a company (Palombini and Nakamura, 2012). The agency conflict may occur if there is lowest level of monitoring in management decision. Manager may decide to invest in positive or negative net present value projects and subsequently influences the investment decision by taking a more flexible working capital policy. This study will provide a practical analysis about the Management of working capital and also the working capital policies to all stakeholders (Creditors, Debtors, Financial institutions, Government etc.). Financial institutions are very conscious about their debt collection; they use these analyses before granting credit decision, which is very useful for them. Creditors are the persons who provide the material on credit and payment received after some period. This analysis is very useful for them to see that how much time the firm is taking to pay its debts or can see the liquidity position of the firm. Working capital components consist on ACP, ICP, APP and CCC. While, The working capital policies provide the approach or strategies used by firms in constructing the working capital management. The strategy will either be aggressive or conservative.

Most of the previous studies are based on impact of working capital on firm performance. Only a few previous studies have considered the impact of working capital policies regarding firm performance. (Afza and Nazir (2008), Al-Shubiri (2011), Palani and Mohideen (2012) and; Chaklader and Shrivastava (2013). Therefore, this study is carried out in order to know whether the firms within the industry use the aggressive or the conservative working capital policies. Working Capital policies play a vital role in firm performance. If the firm does not manage it properly, it adversely affects the firm performance. So, this study is carried out to know that what is the impact of conservative and aggressive policies on firm's performance. 
We aimed to fill the gap identify by Bolek (2013), our study is carried out to know the difference of Bolek result (Poland) in Pakistan Scenario Bolek (2013) examined the relationship among the three approaches (Moderate, Conservative and Aggressive) and the profitability of firms. Bolek (2013) used the sample of Warsaw Stock Exchange firms 1997 to 2007. The study found weak evidence and showed that only the moderate strategy was significant to the profitability of firms. It also found that CATAR and CLTAR did not show the same direction in profitability as measured by ROA and ROE.

The main purpose of this research is to find out what sort of relationship exists between working capital policies and firm's performance. The objectives of this research are:

1) To examine the impact of workingCapital management on firm performance.

2) To examine the impact of working capital policies on firm performance.

3) To provide suggestions to make better working capital policies.

We contributed in the previous study literature in the way of our results, our result shows that the working capital components (APP, ICP, CCC) and the firms' performance are negatively correlated with the ROA and Tobin-q except ACP which shows significant relationship with Tobin Q. All working capital components show the significant relationship with ROE, which indicates that most firms used shareholder's equity to increase firm's value. The relationship between the APP and the firms' performance has shown mixed results. This study shows that the ACP and the firms' performance are positively related. However, the companies are showing the positive relationship between the ACP and the firms' performance as measured by the ROE and Tobin's Q. This indicates that the shorter $\mathrm{ACP}$ in a firm is more preferable to the shareholders. All companies show positive relationship between the CFP and the firms' performance. The relationship indicates that the conservative financing policy is a policy which carries a higher amount of current liabilities will contribute to negative firms' profitability and value. The negative relationship between the CLTAR and the firms' performance indicates that the higher current liabilities in a firm will be a factor towards lower firms' performance. The aggressive financing policy is only significant in all the independent variables. The ROA found CFP and CIP as significant, while in ROE CFP is significant. AIP, CIP and CFP are significant in Tobin Q.

The remainder of the paper organized in the following way. Section 2 about current literature and theoretical premises to explain the linkage between variables and developed several testable hypotheses. Part 3 represents the conceptual framework, research design, methodology. Section 4 includes the findings and section 5 related to the conclusion, recommendations, limitations, implementations, and future research suggestions.

\section{Literature Rreview and Hypothesis Development}

The topic of management of working capital become popular among western states (Mohamad and Saad, 2010). Several studies have also been underway in developing countries to understand whether the results that appear in developed countries can be applied in the developing countries as well. Different views of the importance of management of working capital have induced many researchers to explore this issue. For example, some researchers concentrated on the use of gross operating profit as one of the variables, whereas others prefer to use return on assets (ROA) as one of the variables in the valuation of the company's working capital. By using the gross profit, the focus of the study is the most 
efficient operation of the company to generate profit, while evaluating the performance of the activities focus on the management strength (ROA) of the company in turn owned assets in the company profit. Other variable that is used to assess the management of the company's working capital is the net liquidity balance. Meanwhile, to evaluate the viability of the business, the researchers use the net operating income, gross operating profitability and return on capital as one of the main indicators in related studies. In addition, to measure the performance of the market related to the working capital management of the company, variables like the market to book ratio and Tobin's Q has been used to assess management of the working capital of a company. Clearly, to evaluate the company's working capital, researcher may use different variables and indicators, depending on the goal or aim of the study. However, in many studies, the management of the relationship between working capital and profitability management are even still to be determined. The discrepancy has opened the interest of researchers for further studies in the field of working capital, for instance, whether the profitability affect the decision of working capital of the company or vice versa.

\section{The trade-off theory}

The trade-off theory is among the popular theory that has been discussed on the relationship between management of working capital and profitability of a company. Among the studies that discuss trade off theory are Afza and Nazir (2009) Bellouma ( 2011 ), Bei and Wijewardana ( 2012 ), Napompech ( 2012 ), Bolek ( 2013) and Ukaegbu ( 2014 ). One of the important elements in the working capital management is the liquidity of the firm's asset. Trade off theory balancing the liquidity of the asset and the profitability of a company (2011). In order to create this balance, a company may require a planning on the basic structure of working capital carefully, and any inefficiency in the working capital management can create the crisis of liquidity that reduces the profitability of a business (Ukaegbu, 2014. According to Bei and Wijewardana (2012), the decisions about the management of liquidity level that depend on trade off theory are the management of capital policies.

\section{Working Capital Policies}

\section{Moderate Approach}

In working capital policies, three strategies or approach related to the risk and return, first approach is moderate approach. Moderate approach is a financing strategy that corresponds to the maturity structure of liabilities and the life span of the company's assets. This approach used long term loan and equity to finance the fixed and permanent current assets of the company, while the short-term loan will be used to fiancé the fluctuating current assets.

\section{Conservative Approach}

In this approach, firm would prefer to use long term loan, rather than taking a short-term loan. This approach is usually used by the firm who prefer low risk in their structure of the working capital. This approach would decrease the possibility of not being capable to repay the loan of business and also reduce the risk that occurred from interest rate fluctuations. The advantage of this approach is that the company may incur a high cost of long term.

\section{Aggressive Approach}


In contrast to the conservative approach, a company that uses the aggressive approach would have preferred to have a greater short-term loan level than the long term loan in their capital structure. This approach may require the firm to refinance its loan in the short term more frequently and therefore the company would face a high risk, which is the risk of not being able to get a new loan at a lower cost and risk of changes in the interest rates. However, the advantage of this approach is that the company will get higher profit by using a lower cost of short-term loan.

\section{Average Collection Period and Firm Performance}

The companies that provide longer period in the collection of receivables will give the customers more ease of access to the products. Previous authors that found positive relationship between ACP and firms' profitability are Nziokiet al.(2013), Abuzayed (2012), Sharma and Kumar (2011), Azam and Haider (2011), Chhapra and Naqvi (2012) and Panigrahi (2013).

However, if the companies given the longer period to the customers will incur higher risk to the firm since it could collect cash for the company to use it. Therefore, the shorter receivable period will give more profit to the firm. Previous authors that found negative relationship between ACP and firms' profitability areGill et al. (2010), Mansoori and Muhammad (2012), Garcia et al. (2011), Deloof (2003), Vahid et al. (2012), Ukaegbu (2014), Akinlo (2012), Sabri (2012), Karaduman et al.(2010), Korankye and Adarquah (2013), Charitou et al. (2010), Napompech (2012), Mumtaz et al. (2013), Vishani and Shah (2007), Usama (2012), Bieniasz and Golas (2011) and Bellouma (2011). Therefore, this study hypothesized that:

H1: There is a relationship between the average collection period and the firms' performance.

\section{Average Payable Period and Firm Performance}

Payable period is the time taken by the company in paying their debts. Companies will make late payments to the suppliers because the company use the cash for its operation. Pervious studies that found positive relationship between APP and the firms' performance are Ukaegbu (2014), Nzioki et al. (2013), Azam and Haider (2011), Chhapra and Naqvi (2012), Panigrahi (2013) and Vishani and Shah (2007). However, if the company took log time to pay their debts, the company would lose the opportunity to take discount on early payment. Some authors that bfound negative relationship between APP and the firms' profitability are Mansoori and Muhammad (2012), Garcia et al (2011), Deloof (2003), Vahid et al. (2012), Akinlo (2012), Abuzayed (2012), Sabri (2012), Karaduman et al. (2010), Sharma and Kumar (2011), Korankye and Adarquah (2013), Charitou et al. (2010), Napompech (2012), Mumtaz et al. (2013), Bieniasz and Golas(2011) and Bellouma (2011). Therefore, this study hypothesized that:

H2: There is a relationship between the average payable period and the firms' performance.

\section{Inventory Conversion Period and Firm Performance}

Inventory conversion period is the time taken to convert the inventory into sales. If the company takes longer period to convert the inventory to sales can avoid the shortage of cost. Previous researchers that found positive relationship between ICP and the firms' profitability are Abuzayed (2012), Azam and Haider (2011), Nimalathasan (2010), Chhapra and Naqvi (2012) and Panigrahi (2013). However, if the company takes shorter period it would be better for the company to avoid the additional cost of storage. Previous research that found negative 
relationship between ICP and the firms' profitability are Mansoori and Muhammad (2012), Garcia et al. (2011), Deloof (2003), Vahid et al. (2012), Ukaegbu (2014), Akinlo(2012), Sabri (2012), Karaduman et al. (2010), Sharma and Kumar (2011), Korankye and Adarquah (2013), Charitou et al. (2010), Napompech (2012), Mumtaz et al. (2013), Vishani and Shah (2007), Bieniasz and Golas (2011) and Bellouma (2011). Therefore, this study hypothesized that:

H3: There is a relationship between the inventory conversion period and the firms' performance.

\section{Cash Conversion Cycle and Firms Performance}

Cash conversion cycle is the time taken by a company to convert its resources into cash through sales. If the company takes the shorter time to convert its product into cash is profitable for the company. Previous studies that found negative relationship between CCC and the firms' profitability are Mansoori and Muhammad (2012), Garcia et al. (2011), Deloof (2003), Ukaegbu (2014), Nzioki et al. (2013), Mohamad and Saad (2010), Sabri (2012), Karaduman etal. (2010), Nimalathasan (2010), Charitou et al. (2010), Napompech (2012),Mumtaz et al. (2013), Bieniasz and Golas (2013) and Bellouma (2011). However, some authors that found positive relationship between CCC and the firms' profitability are (Gill et al., 2010; Garcia et al., 2011; Abuzayed, 2012; Sharma and Kumar, 2011; Azam and Haider, 2011; Chhapra and Naqvi, 2012; and Panigrahi, 2013). Therefore, this study hypothesized that:

H4: There is a relationship between the cash conversion cycle and the firms 'Performance.

\section{Investment Policy in Working Capital and Firm Performance}

Aggressive investment policy strained on the minimum investment in current assets compared to the fixed assets while conservative policy strained on the higher investment in current assets compared to the fixed assets. Among the previous studies that had found positive relationship between aggressive investment policy and the firms' profitability are Onwumere et al. (2012), while, negative relationship between aggressive investment and the firms' performance was found by Afza and Nazir (2007, 2008, 2009), Al-Shubiri (2011), Palani and Mohideen (2012) and Chaklader and Shrivastava (2013).For this analysis, the hypotheses are:

H5a: There is a relationship between the aggressive investment policy and the firms' performance.

H5b: There is a relationship between the conservative investment policy and the firms' performance.

\section{Financing Policy in Working Capital and Firm Performance}

Aggressive financing policy consists on the higher proportion in current liabilities compared to the long term debt while the conservative financing policy is focusing on long term debt compared to the current liabilities. Previous studies which had found positive relationship between the aggressive financing policy and the firms' performance is Onwumere et al. (2011). Meanwhile, negative relationship was found by Afza and Nazir (2007, 2008, 2009), Al-Shubiri (2011), Palani and Mohideen (2012) and Chaklader and Shrivastava (2013). For this analysis, the hypotheses are:

H6a: There is a relationship between the aggressive financing policy and the firms' performance.

H6b: There is a relationship between the conservative financing policy and the firms' performance. 


\section{Research Framework}

\section{$\underline{\text { Relationship between Working Capital and Firms' Performance }}$}

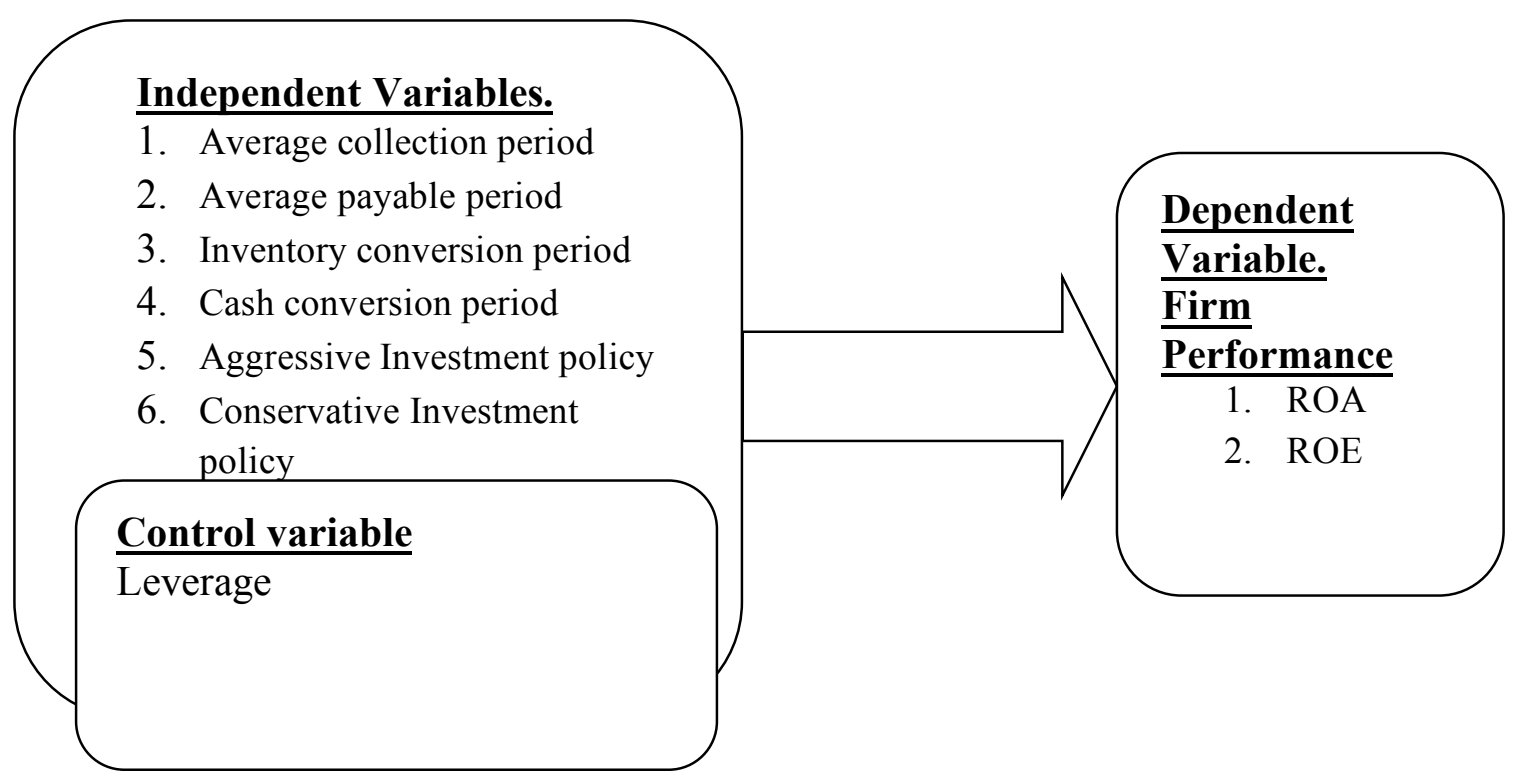

Figure 1: Conceptual Framework

\section{Sample size, Data collection and Methods Data Collection}

All non-financial 65 firms listed at Pakistan stock exchange 100- index is the population of this study. Sample firms were selected on the basis of market capitalization. Maximum firms will be included on the basis of convenience in the data collection.Data was collected through annual reports of companies listed on Pakistanstock exchange for the period 20112015.

\section{Variables Measurement \\ Dependent Variables}

This study uses return of assets and return of equity as a proxy to measure the firms' profitability and Tobin's Q is used to measure the firm's value. Return of equity and return on assets were used by Afza and Nazir (2008); Al-Shubiri (2011); Onwumere (2012); Palani and Mohideen (2012); Bhutto et al. (2011). While Tobin's Q is used by Afza and Nazir (2007, 2009), Mohamad and Saad (2010(, Palani and Mohideen (2012), Pouraghajan and Emamgholipourarchi (2012) and Abuzayed (2012).

Mixed results were found with some proven insignificant relationship between the firm's value and the working capital when using Tobin's Q as the dependent variable. Due to mixed findings, this study uses ROA and ROE to measure the firms' profitability by using the Pakistan Stock exchange firms as the sample size of the study as well as to show the relationship between the firms' value and the working capital management by using Tobin's Q for the period 2011 to 2015.

Return on assets extent the net profitability of a firm from the investment of total assets. Return on equity extent the net profitability of a firm form the shareholders' investment. High ratio of ROA and ROE indicates that the firm uses the equity and assets 
efficiently to generate high profitability. Tobin's Q is a ratio that is used to extent whether the inventory is undervalued or overvalued. High ratio shows that inventory is overvalued which means inventory value is greater than the firms' assets. Low ratio shows that inventory is undervalued which means that the inventory value is less than the firms' assets.

\section{Independent Variables}

This study uses working capital policies and working capital management components as the independent variables. The working capital components are the average payment period, average collection period, inventory conversion period, cash conversion cycle.

Previous studies used all these variables and given significant results (Gill et al, 2010; Mansoori and Muhammad, 2012; Garcia et al., 2011; Deloof, 2003; Mousavi and Jari, 2012 and Ukaegbu, 2014) and therefore this study used the same variables to measure the relationship between the working capital management and the firms' performance using the Pakistan Stock Exchange 100 index non-financial firms. The working capital policy is examined by using the aggressive investment policy and aggressive financing policy ( Afza and Nazir, 2008; Al-Shubiri,2011, Onwumere et al., 2012; Palani and Mohiden, 2012; Bhutto et al., 2011).

A company recorded its accounts receivables in the balance sheet when the company sells goods or rendered services on credit. The company may offer credit period to customers to pay their debt on the basis of company policy whether to provide long term or shorter time. They might also offer a credit period on the basis of historical payment or relationship between customer and the company. The aim of the company to provide credit to customers is to maintain good relations in order to enhance sales.

Accounts payable is the short term liabilities which are recorded in the balance sheet of a company. Trade credit is the best source of short financing. The companies usually buy raw material on credit and take more than a month to pay debt to suppliers, but it depends on the industry and relationship between the firm and suppliers.

Stock is usually held by manufacturing companies. Stock of a company can be in the form of raw material, work in progress or finished goods. Stock is a critical part in a company which holds too big and too little stock will affect the working capital of a company. Larger level of stock in a company may lead to product obsolescence, but smaller level of stock in a company may cause the company to meet a risk where they were stock out.

Cash conversion cycle is the time takes by a company to convert its resources into cash. Generally a company buys raw material on credit and recorded in the balance sheet as payables, while the sale of product $t$ customers on credit is recorded as receivables of a company. It measures the period between cash recovery and cash out.

Current liabilities to total assets and current assets to total assets are the ratios that are used to find out whether a company is using moderate, aggressive or conservative policies in their working capital. Companies with aggressive policy have low current assets and high current liabilities in the working capital. Therefore, low current asset to total assets ratio and high current liabilities to total assets ratio is classified as an aggressive strategy. In contrast, the conservative policy have high current asset to total assets ratio and low current liabilities to total assets ratio.

\section{Control Variables}

Control variables are the variables that influence the relationship but not the area ofInterest by the researcher. Previous researchers also used control variables (Ukaegbu (2014), Deloof (2003), Abuzayed (2012), Karaduman et al. (2010) and Charitou et al. (2010) Afza and Nazir 
(2009), Garcia-Terueland Martinez-Solano (2007), Palani and Mohideen (2012)). like to previous studies, this study used leverage as the control variable. This variable has been shown to be significant in explaining the working capital management (Afza and Nazir (2009); GarciaTeruel and Martinez-Solano (2007); and Palani and Mohideen (2012)).

Table 1: Variables Used in the Study

\begin{tabular}{|l|l|l|}
\hline & Variables & \multicolumn{1}{c|}{ Formula } \\
\hline \multirow{3}{*}{ Dependent } & ROA & Net Income/Total Assets \\
\cline { 2 - 3 } & ROE & Net Income/Total Equity \\
\cline { 2 - 3 } Independent & Tobin's Q & Market value of firm/Book value of assets \\
\cline { 2 - 3 } Variables & APP & Net receivables/Sales*365 \\
\cline { 2 - 3 } & Accounts payable/Cost of goods sold*365 \\
\cline { 2 - 3 } & CCP & Total Inventories/Cost of goods sold*365 \\
\cline { 2 - 3 } & AIP & ACP+ICP-APP \\
\cline { 2 - 3 } & AFP & current assets/Total assets \\
\hline Control & Leverage & Total debts/Total assets \\
\hline
\end{tabular}

\section{Dummy Variable}

Dummy variable is a variable that is used for sorting data into mutually exclusive categories. This study uses dummy variables to examine the relationship between working capital policies and firm's performance. Four variables were used as dummy. They are the aggressive investment policy, the conservative investment policy, the aggressive financing policy and the conservative financing policy.

Previous researches categorized the working capital policies in to three levels which are moderate, aggressive and conservative as to examine the relationship between every working capital policy and firm's performance are Bei and Wijewardana (2012) and Bolek (2013). Bei and Wijewardana (2012) used the different cut-off point to make a distinction between the working capital policies. They only used the current liabilities to total assets as proxy. They recoded the sample as aggressive WCP if the CLTAR is more then 0.2, moderate WCP when the CLTAR range 0.14 to 0.199 and conservative WCP if the CLTAR is less than 0.139 .

In another study by Bolek (2013), the researcher also categorized the WCP into three levels which are moderate, aggressive and conservative. In contrast, Bei and Wijewardana (2012), this study used CATAR and CLTAR to observe the relationship between working capital policies and firms' performance. However, this study does not used cut-off level and only make a distinction between high and low ratio in current assets to total assets and current liabilities to total assets. This study used two proxy of WCP which are investment and financing policies. The sample is noted as aggressive investment policy when the CATAR is 0 to $39 \%$ and conservative investment policy when the CATAR is $60 \%$ and above. Another 
proxy to WCP is financing policy. The sample is noted as aggressive financing policy when CLTAR is $60 \%$ and above and conservative when CLTAR is range from 0 to $29 \%$. As shown in the table 3.1 .

Table 2: Dummy Variables

\begin{tabular}{|l|l|}
\hline \multicolumn{1}{|c|}{ Dummy } & \multicolumn{1}{|c|}{ Explanation } \\
\hline Aggressive Investment Policy & $\begin{array}{l}\text { Noted as 1 when the firms' CATAR( } \\
\text { Current Assets to Total Assets Ratio) } \\
\text { between 0-39\% and noted 0 if not }\end{array}$ \\
\hline Conservative Investment Policy & $\begin{array}{l}\text { Noted as 1 when the firms' CATAR } \\
\text { (Current Assets to Total Assets Ratio) } \\
\text { between 60\% and above, noted 0 if not }\end{array}$ \\
\hline Aggressive Financing Policy & $\begin{array}{l}\text { Noted as } 1 \text { when the firms' CLTAR } \\
\text { (Current Liabilities to Total Assets Ratio) } \\
\text { between 60\% and above, noted 0 if not }\end{array}$ \\
\hline Conservative Financing Policy & $\begin{array}{l}\text { Noted as 1 when the firms' CLTAR } \\
\text { (Current Liabilities to Total Assets Ratio) } \\
\text { between 0-29\% and noted 0 if not }\end{array}$ \\
\hline
\end{tabular}

Below are the WCP and total observations from the sectors used in this study:

Table 3: Investment Policies

\begin{tabular}{|l|l|l|l|}
\hline \multicolumn{1}{|c|}{ AIP } & \multicolumn{1}{|c|}{ MIP } & \multicolumn{1}{c|}{ CIP } & $\begin{array}{c}\text { Total } \\
\text { Observations }\end{array}$ \\
\hline 148 & 82 & 95 & 325 \\
\hline $46 \%$ & $25 \%$ & $29 \%$ & $100 \%$ \\
\hline
\end{tabular}


Table 4: Investment Policies among sectors

\begin{tabular}{|l|c|c|c|c|}
\hline & AIP & MIP & CIP & Total observations \\
\hline Oil And Gas & 14 & 12 & 34 & 60 \\
\hline Power & 14 & 9 & 7 & 30 \\
\hline Fertilizer & 22 & 3 & 0 & 25 \\
\hline Cement & 34 & 6 & 0 & 40 \\
\hline Food & 9 & 6 & 5 & 20 \\
\hline Pharmaceuticals & 7 & 7 & 6 & 20 \\
\hline Automobile & 3 & 3 & 14 & 20 \\
\hline Textile & 18 & 6 & 1 & 25 \\
\hline Misc. & 27 & 30 & 28 & 85 \\
\hline Total & $\mathbf{1 4 8}$ & $\mathbf{8 2}$ & $\mathbf{9 5}$ & $\mathbf{3 2 5}$ \\
\hline
\end{tabular}

Source (PSE-100 index 65 non-financial Companies)

Table 5: Financing Policies

\begin{tabular}{|l|l|l|l|}
\hline \multicolumn{1}{|c|}{ AIP } & \multicolumn{1}{|c|}{ MIP } & \multicolumn{1}{c|}{ CIP } & $\begin{array}{c}\text { Total } \\
\text { Observations }\end{array}$ \\
\hline 42 & 121 & 162 & 325 \\
\hline $13 \%$ & $37 \%$ & $50 \%$ & $100 \%$ \\
\hline
\end{tabular}

Table 6: Financing Policies among Sectors

\begin{tabular}{|l|c|c|c|c|}
\hline & AFP & MFP & CFP & $\begin{array}{c}\text { Total } \\
\text { Observations }\end{array}$ \\
\hline Oil And Gas & 23 & 22 & 15 & 60 \\
\hline Power & 8 & 10 & 12 & 30 \\
\hline Fertilizer & 1 & 9 & 15 & 25 \\
\hline Cement & 0 & 8 & 32 & 40 \\
\hline Food & 0 & 11 & 9 & 20 \\
\hline Pharmaceuticals & 0 & 7 & 13 & 20 \\
\hline Automobile & 4 & 10 & 6 & 20 \\
\hline Textile & 0 & 5 & 20 & 25 \\
\hline Misc. & 6 & 39 & 40 & 85 \\
\hline Total & $\mathbf{4 2}$ & $\mathbf{1 2 1}$ & $\mathbf{1 6 2}$ & $\mathbf{3 2 5}$ \\
\hline
\end{tabular}




\section{Methodology}

Multiple regressions were used to estimate the relationship between the independent and the dependent variables. Specifically, the study on the relationship between working capital and working capital policies is executed by using the Pooled ordinary least squares (OLS) regression. The correlation analysis and the descriptive statistics were carried to examine the relationship between variables.

Working capital management and performance of firm.

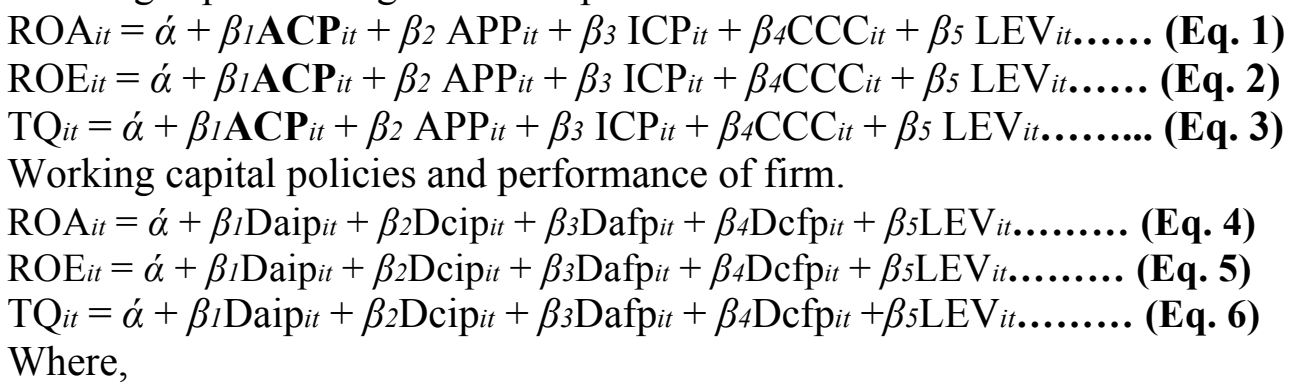

$\mathrm{ROA}=$ Return on Assets, $\mathrm{ROE}=$ Return on Equity, $\mathrm{TQ}=$ Market Return, $\mathrm{ACP}=$ Average collection period, $\mathrm{APP}=$ Average payment period, $\mathrm{ICP}=$ Inventory conversion period, $\mathrm{CCC}=$ Cash conversion cycle, $\mathrm{CATAR}=\mathrm{Current}$ asset to total assets ratio, $\mathrm{CLTAR}=\mathrm{Current}$ liabilities to total assets ratio, $\mathrm{LEV}=\mathrm{Debt}$ to Equity ratio, Daip= Dummy for aggressive investment policy, Dcip= Dummy for conservative investment policy, Dafp = Dummy for aggressive financing policy, Dcfp= Dummy for conservative financing policy, $\dot{\alpha}$ $=$ intercept and $\varepsilon=$ error term.

\section{Result and Discussion}

\section{Descriptive statistics}

Descriptive analysis shows the result in table 4.1. The analysis shows that ROE is 0.332 while ROA and Tobin-q are 0.101 and 0.094 , its means that ROE increase the profitability by $33 \%$, ROA $10 \%$ and Tobin-q $9.4 \%$.ROE is between 0.754 and -0.628 . Whereas, ROA in is between 0.519 and -0.084 . This shows that most of the companies have utilized its assets and shareholders' equity in creating profit to the firm. Tobin's Q is ranged from 0.578 to 0.001 . The maximum days of ACP are 81 days and minimum days of ACP are 17 days. The maximum days of APP are 432 days and minimum 19 days. The ICP is between 416 days to 10 days. The mean value of AIP is 0.231 , AFP 0.030 , CIP 0.166 and CFP 0.316. The maximum leverage is 0.982 and the minimum is 0.048 which is quite low. And this shows that most of the firms depend mostly on the shareholder's equity in their operational activities. The standard deviation measures the dispersion of the data from its mean.

\section{Correlation}

Table 4.2 shows the relationship among the variables within the sample period from year 2011 to 2015. The correlation analysis described that some variables give significant results and some not. AFP is positively correlates to the APP and ICP. On contrary, the AIP is found negatively correlated to the ROA and ROE and tobin q. Five variables show negative correlation with Tobin's Q (ICP, APP, CLTAR, CATAR and CCC). ACP has positive correlation with CCC. APP is positively correlated to ICP, CATAR and CLTAR while negatively correlated to $\mathrm{CCC}, \mathrm{ACP}$ and APP. ICP has positive correlation with $\mathrm{CCC}$, CATAR, CLATR and negative correlation with ACP. CCC and AFP are negatively 
correlated. CATAR and CLTAR are positively correlated with leverage.

The correlation analysis is conducted to find the existence of multicollinearity problem. Multicollinearity problem exists when the correlations value is more than 0.80 (Mohamad and Saad, 2010). Table 4.3 shows that there is no multicollinearity in the data.

However, if the problem exist. To avoid multicollinearity problem in the regression, the working capital components (ACP, APP, ICP and CCC) are regressed independently. The second method to test multicollinearity is by using the VIF. If the variable shows VIF value is more than 10, the variable must be omitted. The below VIF results show the results range 1 to 10. This show that the value is good and in the range of optimum value, so it shows no presence of autocorrelation. The result of autocorrelation test gave $\mathrm{D}-\mathrm{W}$ statistic a value of 2.058. it is the range of 0 to 4 which shows an optimum value. It can lead to conclusion that there is no autocorrelation and multicollinearity in the data.

\section{Multicollinearity Test}

\begin{tabular}{ll}
\multicolumn{2}{l}{ VIF Value } \\
\hline \hline \multicolumn{2}{l}{ VariableVIF } \\
\hline \hline ACP & 1.140283 \\
APP & 6.384775 \\
ICP & 9.068816 \\
CCC & 6.115356 \\
AFP & 1.263376 \\
AIP & 1.928113 \\
CFP & 1.995925 \\
CIP & 1.439546 \\
C & 5.560932 \\
\hline \hline
\end{tabular}

The result shows that no variable has VIF value greater than 10. So, its mean that there is no multicollinearity in the data.

\section{Regression Analysis Results}

\section{Relationship between Working Capital Management and Firms' Performance}

Table 4.4 shows the results for the firms when performance is measured by ROA. The result shows that working capital components (ACP, APP, ICP and CCC) do not have any significant relationship with ROA. Therefore, $\mathrm{H} 1, \mathrm{H} 2, \mathrm{H} 3$ and $\mathrm{H} 4$ are rejected. However, the study found that working capital policies measured by CATAR consistently show significant results. In other words, the higher the CATAR is, the higher the firms' profitability will be. This implies that the firms using a lot of current assets in their operation. Hence, according to the theory, a higher usage of current asset means that the firms follow the conservative strategy. Hence, H5a and H5b are accepted. However, the results for CLTAR are mixed using OLS the relationship is negatively significant to ROA. The control variable leverage has significant relationship.

Table 4.5 shows the results that working capital components (ACP, APP, ICP and CCC) have significant relationship with ROE. APP and CCC are positively correlated with 
ROE. Therefore, H1, H2, H3 and $\mathrm{H} 4$ are accepted. However, the study found that working capital policies measured by CATAR and CLTAR consistently show insignificant results when the analysis was done by using OLS. Higher current asset implies that most of the companies are using the conservative approach and therefore $\mathrm{H} 5 \mathrm{a}$ and $\mathrm{H} 5 \mathrm{~b}$ are rejected. The control variable shows the insignificant relationship with $\mathrm{ROE}$

The relationship between the working capital and the firm value measured by Tobin's Q is shown in Table 4.6. The working capital components (APP, ICP and CCC) do not have a significant relationship with Tobin'sQ when the relationship is measured by using OLS except the ACP which shows the positive relationship. Therefore, $\mathrm{H} 1, \mathrm{H} 2, \mathrm{H} 4$ are rejected. The working capital policies measured by CATAR shows the significant relationship. Whereas, CLTAR and Tobin's Q are showing insignificant relationship. The control variable that shows insignificant relationship with Tobin's Q.

Table 7: Regression Analysis

\begin{tabular}{|l|l|l|l|}
\hline \multicolumn{3}{|l|}{ Dependent Variable: ROA } & \\
\hline Variable & Coefficient & & Std. Error \\
\hline ACP & -0.000289 & & $(0.000369)$ \\
\hline APP & 0.08119 & & $(0.077338)$ \\
\hline ICP & -0.097624 & & $(0.074947)$ \\
\hline CCC & 0.091598 & & $(0.063685)$ \\
\hline CLTAR & 0.225191 & & $(0.234969)$ \\
\hline CATAR & $-0.397648 * * *$ & & $(0.143692)$ \\
\hline LEVR & $-34.10014 * * *$ & & $(14.31066)$ \\
\hline C & 30.51763 & & $(6.263962)$ \\
\hline & & & \\
\hline $\begin{array}{l}\text { (Note) } \\
* * * \text { Significant at } 0.01\end{array}$ & & & \\
\hline$* *$ Significant at 0.05 & & & \\
\hline$*$ Significant at 0.1 & & \\
\hline
\end{tabular}

Table 8 Regression Analysis

\begin{tabular}{|c|c|l|l|}
\hline \multicolumn{2}{|l|}{ Dependent Variable: ROE } & \\
\hline Variable & Coefficient & & Std. Error \\
\hline ACP & $-0.001208 * * *$ & & $(0.000473)$ \\
\hline APP & $0.259643 * * * *$ & & $(0.095972)$ \\
\hline ICP & $-0.325876 * * *$ & & $(0.093786)$ \\
\hline CCC & $0.307811 * * * *$ & & $(0.079927)$ \\
\hline FINCLTAR & 0.337898 & & $(0.288998)$ \\
\hline
\end{tabular}




\begin{tabular}{|c|c|l|c|}
\hline INVCATAR & $-0.27536^{*}$ & & $(0.170323)$ \\
\hline LEVR & $-26.15557^{*}$ & & $(17.21146)$ \\
\hline C & 13.23397 & & $(6.682243)$ \\
\hline & & & \\
\hline
\end{tabular}

\section{Table 9 Regression Analysis}

\begin{tabular}{|l|l|l|l|}
\hline Dependent Variable: Tobin_Q & \\
\hline Variable & Coefficient & & Std. Error \\
\hline ACP & $0.001128^{* * *}$ & & $(0.000262)$ \\
\hline APP & -0.019084 & & $(0.047133)$ \\
\hline ICP & -0.021507 & & $(0.045699)$ \\
\hline CCC & 0.017556 & & $(0.038799)$ \\
\hline FINCLTAR & -0.014358 & & $(0.143234)$ \\
\hline INVCATAR & $-0.23031^{* * *}$ & & $(0.087719)$ \\
\hline LEVR & -6.505489 & & $(8.653627)$ \\
\hline C & 19.10606 & & $(3.820246)$ \\
\hline & & & \\
\hline
\end{tabular}

\section{Relationship between Working Capital Policies and Firms' Performance}

Table 4.7 shows the relationship between the working capital policies and the firms' performance of the companies. The variables that show significant results with firms' performance are D(AIP), D(CFP), D(CIP) and leverage. D(AIP) shows the positive significant relationship with ROA. This indicates that the conservative financing policy will increase the profit for the firm but at the same time the conservative investment policy will increase the shareholders' value. The entire control variable shows significant results with the firms' performance. Therefore, this study accepts H5a,H5b and H6b.

Table 4.8 shows a relationship between the working capital policies and the firms' performance. The variables that show significant results are $\mathrm{D}(\mathrm{CFP}), \mathrm{D}(\mathrm{AIP})$ and leverage. $\mathrm{D}$ (AIP) shows the positive significant relationship with ROA. Its mean that the firms that used the AIP have positive impact on their profitability. Thus this study is rejects H5b, and H6a. Table 4.9 shows a relationship between the working capital policies and the firms' performance. Dummy variables of the working capital policy $\mathrm{D}(\mathrm{CFP}), \mathrm{D}(\mathrm{AIP})$ and $\mathrm{D}(\mathrm{CIP})$ have shown a significant relationship with the firms' performance. This indicates that the working capital policy can influence the firms' performance. D(AFP) is negatively related with the firms' performance which indicates that the aggressive strategy will reduce the firms' performance. This indicates that the conservative investment policy and the conservative financing policy will increase the firms' profitability and shareholders' value. Hence, this study accepts H5a, H5b and H6b. 
Table 10 Regression Analysis WCP

\begin{tabular}{|l|l|l|l|}
\hline \multicolumn{4}{|c|}{ Dependent Variable: ROA } \\
\hline Variable & Coefficient & & Std. Error \\
\hline ACP & -0.000674 & & $(0.00047)$ \\
\hline APP & $0.190186 * *$ & & $(0.097576)$ \\
\hline ICP & -0.162023 & & $(0.098532)$ \\
\hline CCC & $0.138819 *$ & & $(0.083046)$ \\
\hline DAFP & -1.795589 & & $(18.33777)$ \\
\hline DAIP & $10.73517 *$ & & $(9.04621)$ \\
\hline DCFP & $-37.53822 * * *$ & & $(7.075563)$ \\
\hline DCIP & $-27.07711^{* * *}$ & & $(8.709709)$ \\
\hline LEVR & $-97.69453 * *$ & & $(14.03903)$ \\
\hline C & 83.88375 & & $(6.68152)$ \\
\hline
\end{tabular}

Table 11 Regression Analysis WCP

\begin{tabular}{|l|l|l|l|}
\hline \multicolumn{5}{|c|}{ Dependent Variable: ROE } \\
\hline Variable & Coefficient & & Std. Error \\
\hline ACP & $-0.003206^{* * *}$ & & $(0.000578)$ \\
\hline APP & $0.456743^{* * *}$ & & $(0.120022)$ \\
\hline ICP & $-0.600506 * *$ & & $(0.121197)$ \\
\hline CCC & $0.542492^{* * *}$ & & $(0.102149)$ \\
\hline AFP & 20.48241 & & $(22.55608)$ \\
\hline AIP & $2.294602 * *$ & & $(11.12714)$ \\
\hline CFP & $-22.44467 * * *$ & & $(8.703182)$ \\
\hline CIP & -13.92692 & & $(10.71324)$ \\
\hline LEVR & $-55.73585 * * *$ & & $(17.26848)$ \\
\hline C & 44.11017 & & $(8.218496)$ \\
\hline
\end{tabular}

Table 12 Regression Analysis WCP

Dependent Variable: Tobin_Q

\begin{tabular}{|l|l|l|l|}
\hline \multicolumn{1}{|c|}{ Variable } & \multicolumn{1}{c|}{ Coefficient } & & \multicolumn{1}{c|}{ Std. Error } \\
\hline ACP & $0.003375^{* * *}$ & & $(0.000298)$ \\
\hline APP & 0.038729 & & $(0.061912)$ \\
\hline ICP & -0.027345 & & $(0.062518)$ \\
\hline CCC & 0.021436 & & $(0.052692)$ \\
\hline DAFP & -7.748333 & & $(11.63524)$ \\
\hline
\end{tabular}




\begin{tabular}{|l|l|l|l|}
\hline DAIP & $-11.12261 * *$ & & $(5.739781)$ \\
\hline DCFP & $-23.62933 * * *$ & & $(4.489414)$ \\
\hline DCIP & $-20.28819 * * *$ & & $(5.526273)$ \\
\hline LEVR & $-50.50734 * * *$ & & $(8.907701)$ \\
\hline C & 53.30874 & & $(4.239396)$ \\
\hline
\end{tabular}

\section{Conclusion and Recommendations}

This study shows that the working capital components (APP, ICP, CCC) and thefirms' performance are negatively correlated with the ROA and Tobin-q except ACP which shows significant relationship with Tobin_q. All working capital components show the significant relationship with ROE, which indicates that most firms used shareholder's equity to increase firm's valueThe relationship between the APP and the firms' performance has shownmixed results. This study shows that the ACP and the firms' performance are positively related. However, the companies are showing the positive relationship between the ACP and the firms' performance as measured by the ROE and Tobin's Q. This indicates that the shorter ACP in a firm is more preferable to the shareholders.

All companies show positive relationship between the CFP and the firms' performance. The relationship indicates that the conservative financing policy is a policy which carries a higher amount of current liabilities will contribute to negative firms' profitability and value. The negative relationship between the CLTAR and the firms' performance indicates that the higher current liabilities in a firm will be a factor towards lower firms' performance.

The study on the working capital policies and the firms' performance provides more precise results when it was conducted by using the dummy variables. All companies show that the working capital policies may affect the firms' performance. The aggressive financing policy is only significant in all the independent variables. The ROA found CFP and CIP as significant, while in ROE CFP is significant. AIP, CIP and CFP are significant in Tobin_q. The control variable in this study is the leverage. The leverage has shown positive relationship to the firms' performance in ROA in working capital components, while show the significant relationship in working capital policies to the firm's performance. The leverage and the firms' value show a negative relationship which indicates that the shareholders' tend to give more value to the firm if they used the lower leverage financing. However, the profitability of the firms will be higher if they used more leverage financing. In conclusion, the working capital management and the working capital policies provide significant relationship to the firms' performance. Different results occurred due to the different working capital practices among companies which has been supported by Weinraub and Visscher (1998), Salawu (2006), Afza and Nazir (2008). Most companies found that the working capital components (ACP, APP, ICP and CCC) and the firms' performance are negatively related. This relationship was supported by the previous studies done by Deloof (2003), Charitou et al. (2010), Karaduman et al. (2010), Garcia et al. (2011), Mansoori and Muhammad (2012), Napompech (2012), Sabri (2012), Mumtaz et al. (2013) and Ukaegbu (2014). On the Other hand, the positive relationship between the CATAR and the firms' performance has been supported by Afza and Nazi(2008), Al-Shubiri (2011), Palani and Mohideen (2012) and; Chaklader and Shrivastava (2013). The relationship between the CLTAR and the firms' profitability are significantly negative which was supported by the previous findings by Afza and Nazir (2008), Al-Shubiri (2011), Palani and Mohideen (2012). While, the significant relationship found between the CLTAR and the firms' performance has been supported by Afza and Nazir (2009) and; Palani and Mohideen (2012). 
All variables show significant results which show the existing of a relationship between the working capital management and the firms' performance. For the first finding the relationship between the working capital components (APP, ACP, ICP and CCC) and the firms' performance. APP is found significantly positive on the ROE, while APP is negatively related to the ROA and Tobin-Q in the analysis.

ACP is found significantly positive on the ROE and Tobin-Q, while ACP is negatively related ROA in the analysis. ICP and CCC are found significantly positive with ROE, while negatively with ROA and Tobin-q. For the analysis, the positive relationship between the ACP and the performance was shown as measured by the ROE and Tobin-Q show that a longer time taken given to the customers to collect the debts will increase the firms' profitability due to the greater access of the products. The negative relationship between the ACP and the firms' profitability which is found in ROA shows that the firms speed up the process of collecting the account receivables as it can avoid bad debts. The ACP and the Tobin's Q are positively related, which indicates that the shareholders' will give more value if the firms grant the customers with a longer credit policy.

APP is found positively related with ROE. This shows that the companies will be more profitable if they delay their payments for the payables. On the other hand, APP is significantly negative with the ROA and Tobin-q. This shows that the companies are managing their working capital efficiently by reducing the cost in the interest payment in the payables to get a higher profit. The APP and the Tobin's Q are found negative relationship which shows that the shareholders' value will increase if the firms pay their creditors' on time.

The negative relationship is found between the ICP and the firms' profitability (ROA and Tobin-Q) indicates that these companies are maintaining the low cost in storage and the insurance to obtain a higher profit. However, the ICP and the ROE is found positively related which indicates that the companies will get more profit if the firms have higher inventory turnover period. The availability of stocks in delivering the customers' necessity will reduce the ordering cost of a firm and therefore will increase the firms' profitability. The ICP and the Tobin'sQ is found to be negatively related which indicates that the shareholders' are giving more value if the firms has longer conversion period in the inventory.

The CCC and the firms' profitability are negatively related, which shows that the most of the companies are getting higher profit when reducing thee period in converting the sales to cash. The CCC and the Tobin's Q are negatively related. While, positive relationship between the CCC and the ROE is found which, indicates that Shareholders' are giving more value if firms have longer cash conversion cycle, delaying the debt collection, delaying the payments to the creditors and have a long inventory turnover.

The second findings discussed the aggressive working capital management which comprises of the aggressive investment policy, Conservative investment policy, aggressive financing policy and the conservative financing policy. Aggressive investment policy and the firms' performance (ROA, ROE and Tobin's Q) are negatively related. On the other hand, the aggressive financing policy and the firms' performance are negatively related in most of the companies. However, the AIP and the Tobin-Q indicates the positive relationship to firms' performance. This indicates that the firms' performance will be affected by using aggressive working capital policies in most of the firms. The analysis shows that AIP is positively related to firms' performance.

A precise study is done to estimate the relationship between the working capital policies and the firms' performance. The study has found that the working capital policies will affect the firms' performance. The AIP is positively related to the firms' performance. 
The AFP and the firms' performance are negatively related in most of the companies. This study also found that the CIP and the CFP showed a positive relationship with the firms' performance. The CIP and the firms' performance is negatively related in some companies. In addition, the CFP and the firms' performance is positively related in most of the companies.

Overall, most of the companies show negative relationship between the working capital management and the firms' performance. This relationship was proven by using the working capital components and the working capital policies. A firm which has a shorter period in collecting their debts, pay and inventory cycle will increase the firms' profitability and value. While, firms with the conservative working capital policies which holds a higher current assets and a lower current liabilities tend to increase the firms' performance compared to the firms which applied the aggressive working capital policies.

\section{Limitation of Study and Future Research Suggestion}

There are several limitations in this study. The first limitation is the time period. This study is conducting within three to four months. Due to the time limitation, this study could not observed the working capital practices in all firms listed in Pakistan stock exchange. The second limitation is the small sample size. This study is only limited to non-financial sector. This research only related to non-financial firms listed in Pakistan stock exchange and so covers the limited geographic area of focus so it can explain the effects of working capital policies on the performance of non-financial firms.

Working capital is an interesting area since it comprises of short term financing and investment decision. Due to the lack of findings in several sectors listed in Pakistan stock exchange, future research should be done by focusing on the other sectors which are the technology and the finance sectors. The technology sector can be done by increasing the percentage taking in overall sample. The finance sector would give different results because of the different accounting treatment. Moreover, the future research should use a larger sample size to get more significant results.

\section{References}

Abuzayed, B. (2012). Working capital management and firms' performance in emerging markets: the case of Jordan. International Journal of Managerial Finance, 8(2). 155-179.

Afza, T., \& Nazir, M. S. (2007). Is it better to be aggressive or conservative in managing working capital? Journal of Quality and Technology Management, 3(2). 11-21.

Afza, T., \& Nazir, M. S. (2008). Working Capital Approaches and Firm's Returns. Pakistan Journal of Commerce and Social Sciences, 25-36.

Azam, M., \& Haider, S. I. (2011). Impact of Working Capital Management on Firms' Performance: Evidence from Non-Financial Institutions of KSE-30 index. Interdisciplinary Journal of Contemporary Research in Business, 3(5), 481-492.

Bei, Z., \& Wijewardana, W. P. (2012). Working capital policy practice: Evidence from Sri Lankan companies. Procedia-Social and Behavioral Sciences , 40(1), 695-700.

Bolek, M. (2013). Working Capital Management, Profitability and Risk - Analysis of Companies Listed on the Warsaw Stock Exchange. Financial Internet Quaterly, 9(3), 1-10.

Chaklader, B., \& Shrivastava, N. (2013). Relationship of Working Capital Management with Firm's Profitability during the Period of Global Slowdown: An Empirical Study of Manufacturing Firms in India . Research Journal of Economics and Business Studies, 2(3), 41-50.

Charitou, M. S., Elfani, M., \& Lois, P. (2010). The Effect of Working Capital Management on Firm's Profitability: Empirical Evidence from an Emerging Market. Journal of Business and Economics Research, 8(12)63-68.

Deloof, M. (2003). Does Working Capital Management Affect Profitability of Belgian Firms? 
Journal of Business Finance and Accounting, 30(3-4), 573-587.

Forghani, M., Shirazipour, M., \& Hosseini, A. (2013). Impact of Working Capital Management on Firms Performance. Journal of Basic and Applied Scientific Research, 3(7), 943-947.

Garcia, J. F., Martins, F. V., \& Brandao, E. F. (2011). The Impact of Working Capital Management upon Companies' Profitability: Evidence from European Companies . FEP Working Papers, $1-35$.

Karaduman, H. A., Akbas, H. E., Ozsozgun, A., \& Durer, S. (2010). Effects of working capital management on profitability: The case for selected companies in the Istanbul Stock Exchange. International Journal of Economics and Finance Studies, 2(2), 47-54.

Korankye, T., \& Adarquah, R. S. (2013). Empirical Analysis of Working Capital Management and its Impact on the Profitability of Listed Manufacturing Firms in Ghana. Research Journal of Finance and Accounting, 4(1),124-131.

Mansoori, E., \& Muhammad, J. (2012). The effect of working capital management on firm's profitability: Evidence from Singapore. Interdisciplinary Journal of Contemporary Research in Business, 472-486.

Mohamad, \& Saad, N. M. (2010). Working Capital Management: The Effect of Market Valuation and Profitability in Malaysia. International Journal of Business and Management, 140-147.

Mumtaz, A., Rehan, M., Rizwan, M., Murtaza, F., Jahanger, A., \& Khan, H. A. (2013). Impact of Working Capital Management on firms' performance: Evidence from Chemical Sector listed firms in KSE-100 index . IOSR Journal of Business and Management, 93-100.

Napompech, K. (2012). Effects of Working Capital Management on the Profitability of Thai Listed Firms. International Journal of Trade, Economics and Finance, 3(3). 227-232.

Nzioki, P. M., Kimeli, S. K., Abudho, M. R., \& Nthiwa, J. M. (2013). Management of working capital and its effect on profitability of manufacturing companies listed on Nairobi Stock Exchange (NSE), Kenya. International Journal of Business and Finance Management Research, 3542.

Palani, A., \& Mohideen, A. P. (2012). Impact of aggressive working capital management policy on firms' profitability. International Journal of Researchin Commerce \& Management, 49-53.

Palombini, N. V., \& Nakamura, W. T. (2012). Key factors in working capital management in the Brazilian market. Revista de Administração de Empresas, 52(1), 55-69.

Panigrahi , A. K. (2013). Negative Working Capital and Profitability: An Empirical Analysis of Indian Cement Companies. International Journal of Research, 4(6) 41-46.

Sabri, T. B. (2012). Different Working Capital Policies and the Profitability of a Firm. International Journal of Business and Management, 7(15), 50-60.

Salawu, R. O. (2006). Industry Practice and Aggressive Conservative Working Capital Policies in Nigeria. European Journal of Scientific Research, 13(3), 294-304.

Sharma, A. K., \& Kumar, S. (2011). Effect of Working Capital Management on Firm Profitability: Empirical Evidence from India. Global Business Review, 12(1), 159-173.

Ukaegbu, B. (2014). The significance of working capital management in determining firm profitability: Evidence from developing economies in Africa. Research in International Business and Finance, 3(1), 1-16.

Usama, M. (2012). Working Capital Management and its effect on firm's profitability and liquidity: In other food sector of (KSE) Karachi Stock Exchange. Arabian Journal of Business and Management Review, 34(969), 1-12

Vahid, T. K., Elham, G., Mohsen, A. K., \& Mohammad Reza, E. (2012). Working Capital Management and Corporate Performance: Evidence from Iranian Companies. Procedia Social Behavioral Sciences, 62. 1313-1318.

Vishnani, S., \& Shah, B. K. (2007). Impact of Working Capital Management Policies on Corporate Performance-An Empirical Study. Global Business Review. 8(2), 267-281. 